\title{
PROTEIN-LIPID RELATIONSHIPS IN HUMAN PLASMA. III. IN PREGNANCY AND THE NEWBORN ${ }^{1}$
}

\author{
BY ELLA M. RUSS, HOWARD A. EDER,2 AND DAVID P. BARR WITH THE TECHNICAL \\ ASSISTANCE OF JULIE RAYMUNT
}

(From the Department of Medicine, The New York Hospital-Cornell Medical Center, New York, N. Y.)

(Submitted for publication July 26, 1954; accepted August 13, 1954)

This study of pregnant women and their newborn infants was undertaken as a part of a more extensive investigation of factors that modify the interrelations of proteins and lipids in human plasma (1-3).

The composition of maternal and fetal blood has been examined by many observers who, however, have usually focussed attention either on proteins or lipids. Electrophoretic studies of proteins have been made by Longsworth, Curtis, and Pembroke (4) who analyzed both serum and plasma; by Lagercrantz (5) and Moore, DuPan, and Buxton (6) who examined only serum; and by Macy and Mack (7) whose monograph was devoted to an inquiry concerning plasma proteins in human reproduction. There is consensus that maternal plasma has less than normal concentration of albumin and a greater than normal concentration of alpha and beta globulins while gamma globulins are unchanged or only slightly decreased. These electrophoretic analyses of the cord plasma have shown lower than normal concentration of total protein which is chiefly attributable to a marked reduction in the concentration of alpha and beta globulins. Numerous investigators (8-10) have shown that in maternal blood the concentration of cholesterol and phospholipids is greater than normal while in blood from the umbilical cord at the time of birth it is notably reduced (11-13).

In the present study, utilization of the microfractionation method No. 10 of Cohn and his coworkers (14) has made possible the separation of the lipoproteins of plasma into two fractions which together contain essentially all of the lipids. By

1 These studies have been aided by a grant from the U. S. Public Health Service, by support from the Commonwealth Fund and the Albert and Mary Lasker Foundation, and by gifts from Mrs. Katherine Lilly Conroy.

2 Present address: National Heart Institute, Bethesda, Maryland. such separation and by subsequent analyses of the protein and lipid constituents of each fraction, it is possible to define their relationships in a manner not attainable by analyses of the unfractionated plasma.

\section{SUBJECTS}

Twenty-seven pregnant women who were free from detectable abnormalities during their prepartum examination at The New York Hospital served as subjects for the study. They varied in age from 19 to $40 ; 13$ were primipara and 4 were completing their fourth pregnancy. From each subject blood samples were taken immediately following the delivery. In 25 of the cases observations were made on blood samples drawn simultaneously from the placental end of the umbilical cord.

\section{METHODS}

The microfractionation method of Cohn and his coworkers (14) was used for separation of proteins. In this study the procedure was carried out in only three stages with isolation of Fraction IV $+\mathrm{V}+\mathrm{VI}$, Fraction II, and Fraction. I + III. Analyses for protein, cholesterol, and phospholipids were made on the unfractionated plasma and each of its fractions. Because of the extremely small amounts of phospholipids in Fraction II, the determination was omitted.

Details of the procedure involving fractionation and the analytical methods for proteins, cholesterol, and phospholipids have been presented in a previous publication (1). They have not been significantly modified for the present work.

The distribution of protein components in the various fractions was studied electrophoretically by the moving boundary method and also by paper ionophoresis which was adapted to the purpose of identifying lipoproteins.

The moving boundary method was performed on ACD plasma and the three fractions using an Aminco Stern apparatus with a standard analytical cell. Details of this procedure and the preparation of samples prior to electrophoresis have been described in a previous publication (1).

Paper electrophoresis was carried out by a modification and combination of several methods (15-17). A vapor tight plastic chamber was employed and the experiments were conducted at 20 to $25^{\circ} \mathrm{C}$. using veronal-citrate buffer $\mathrm{pH} 8.6, \Gamma / 20.05$; a rectangular sheet of Whatman 3 
TABLE I

Concentration and distribution of proteins, cholesterol, and phospholipids in $(A)$ maternal plasma, $(B)$ cord plasma

\begin{tabular}{|c|c|c|c|c|c|c|c|c|c|c|c|c|}
\hline \multirow[b]{2}{*}{ Subject } & \multirow[b]{2}{*}{$\begin{array}{l}\text { Age } \\
\text { and } \\
\text { Sex }\end{array}$} & \multirow{2}{*}{$\begin{array}{c}\text { Total } \\
\text { protein } \\
\text { Gr.lod ml. } \\
\text { Kjeldahl }\end{array}$} & \multicolumn{3}{|c|}{$\begin{array}{c}\text { Protein in fractions } \\
\mathrm{Gm} / 100 \mathrm{ml} . \\
\text { Biuret }\end{array}$} & \multirow{2}{*}{$\begin{array}{c}\text { Total } \\
\text { cholesteral } \\
\text { Mg./100 ml. }\end{array}$} & \multicolumn{3}{|c|}{$\begin{array}{l}\text { Cholesterol in } \\
\text { fractions } \\
\text { Me. } / 100 \mathrm{ml} .\end{array}$} & \multirow{2}{*}{$\begin{array}{c}\text { Total } \\
\text { phoepholipid } \\
\text { ME. } / 100 \text { ml. }\end{array}$} & \multicolumn{2}{|c|}{$\begin{array}{c}\text { Phospholipid in } \\
\text { fractions } \\
\text { M8. } / 100 \text { ml. }\end{array}$} \\
\hline & & & $\begin{array}{c}\mathrm{IV}+\mathrm{V} \\
+\mathrm{VI}\end{array}$ & II & I +III & & $\begin{array}{c}I V+V \\
+V I\end{array}$ & II & I +III & & $\begin{array}{c}\begin{array}{c}I V+V \\
+V I\end{array}\end{array}$ & I +III \\
\hline \multicolumn{13}{|c|}{ A. Maternal Plasma at Time of Delivery } \\
\hline $\begin{array}{l}\text { Lee } \\
\text { Hof } \\
\text { Wal } \\
\text { Arb } \\
\text { Fuh } \\
\text { Wil } \\
\text { Cly } \\
\text { Coh } \\
\text { Vog } \\
\text { Lub } \\
\text { Lau } \\
\text { Wer } \\
\text { Lea } \\
\text { Nor } \\
\text { Lug } \\
\text { Sch } \\
\text { Har } \\
\text { Bro } \\
\text { Gil } \\
\text { Sev } \\
\text { San } \\
\text { Sta } \\
\text { Mot } \\
\text { Mah } \\
\text { Hef } \\
\text { Pop } \\
\text { Tor }\end{array}$ & $\begin{array}{l}20 \\
22 \\
21 \\
30 \\
27 \\
27 \\
27 \\
21 \\
20 \\
24 \\
24 \\
39 \\
39 \\
23 \\
26 \\
35 \\
40 \\
20 \\
30 \\
33 \\
21 \\
22 \\
\\
22 \\
24 \\
22 \\
21\end{array}$ & $\begin{array}{l}6.20 \\
7.40 \\
6.20 \\
6.87 \\
6.56 \\
6.20 \\
7.02 \\
6.61 \\
6.40 \\
6.70 \\
6.68 \\
7.13 \\
6.74 \\
5.08 \\
6.41 \\
6.82 \\
7.18 \\
6.48 \\
6.36 \\
5.99 \\
6.87 \\
6.31 \\
6.60 \\
6.13 \\
6.96 \\
7.27 \\
6.20\end{array}$ & $\begin{array}{l}3.97 \\
4.30 \\
3.88 \\
4.50 \\
4.25 \\
3.74 \\
4.43 \\
4.28 \\
3.86 \\
4.12 \\
4.12 \\
4.33 \\
4.42 \\
3.08 \\
4.31 \\
4.51 \\
3.98 \\
4.45 \\
4.06 \\
3.82 \\
4.42 \\
4.10 \\
4.26 \\
4.24 \\
4.24 \\
4.66 \\
4.18\end{array}$ & $\begin{array}{l}0.56 \\
0.70 \\
0.63 \\
0.68 \\
0.65 \\
0.69 \\
0.91 \\
0.88 \\
0.71 \\
0.67 \\
0.78 \\
0.47 \\
0.77 \\
0.44 \\
0.80 \\
0.59 \\
1.13 \\
0.95 \\
0.77 \\
0.64 \\
0.59 \\
0.60 \\
0.67 \\
0.61 \\
0.62 \\
0.70 \\
0.54\end{array}$ & $\begin{array}{l}1.86 \\
2.58 \\
1.89 \\
2.20 \\
2.20 \\
2.22 \\
2.00 \\
1.96 \\
2.09 \\
2.08 \\
1.94 \\
2.57 \\
1.82 \\
1.76 \\
1.89 \\
2.03 \\
2.34 \\
2.05 \\
1.90 \\
1.69 \\
2.19 \\
2.13 \\
1.81 \\
1.58 \\
2.31 \\
2.24 \\
2.05\end{array}$ & $\begin{array}{l}250 \\
439 \\
291 \\
280 \\
300 \\
231 \\
356 \\
250 \\
236 \\
281 \\
270 \\
485 \\
244 \\
209 \\
292 \\
283 \\
283 \\
314 \\
222 \\
254 \\
321 \\
247 \\
252 \\
235 \\
296 \\
274 \\
226\end{array}$ & $\begin{array}{r}64 \\
68 \\
51 \\
60 \\
77 \\
28 \\
83 \\
57 \\
41 \\
77 \\
75 \\
48 \\
78 \\
27 \\
64 \\
78 \\
71 \\
71 \\
88 \\
53 \\
57 \\
45 \\
83 \\
46 \\
106 \\
64 \\
55\end{array}$ & $\begin{array}{r}0 \\
3 \\
2 \\
4 \\
1 \\
2 \\
4 \\
1 \\
5 \\
4 \\
5 \\
4 \\
0 \\
3 \\
2 \\
2 \\
10 \\
5 \\
3 \\
3 \\
1 \\
0 \\
0 \\
0 \\
0 \\
4 \\
4\end{array}$ & $\begin{array}{l}177 \\
358 \\
216 \\
195 \\
205 \\
184 \\
262 \\
181 \\
189 \\
200 \\
183 \\
402 \\
152 \\
167 \\
219 \\
192 \\
197 \\
229 \\
125 \\
196 \\
263 \\
203 \\
143 \\
191 \\
194 \\
210 \\
164\end{array}$ & $\begin{array}{l}373 \\
390 \\
346 \\
316 \\
331\end{array}$ & $\begin{array}{r}131 \\
129 \\
116 \\
142 \\
187 \\
82\end{array}$ & $\begin{array}{l}146 \\
279 \\
237 \\
192 \\
202 \\
183 \\
\\
207 \\
\\
370\end{array}$ \\
\hline $\begin{array}{l}\text { Mea } \\
\text { S.D. }\end{array}$ & & $\begin{array}{r}6.57 \\
\pm 0.51\end{array}$ & $\begin{array}{r}4.17 \\
\pm 0.32\end{array}$ & $\begin{array}{r}0.69 \\
\pm 0.15\end{array}$ & $\begin{array}{r}2.05 \\
\pm 0.24\end{array}$ & $\begin{array}{r}282 \\
\pm 62.2\end{array}$ & $\begin{array}{r}63 \\
\pm 18.2\end{array}$ & $\begin{array}{r}3 \\
\pm 2.3\end{array}$ & $\begin{array}{r}207 \\
\pm 58.5\end{array}$ & $\begin{array}{r}372 \\
+80\end{array}$ & $\begin{array}{r}139 \\
\pm \quad 34\end{array}$ & $\begin{array}{r}206 \\
\pm 63\end{array}$ \\
\hline \multicolumn{13}{|c|}{ Normal non-pregnant women (aged 18-35) } \\
\hline $\begin{array}{l}\text { Mea } \\
\text { S.D. }\end{array}$ & & $\begin{array}{r}6.71 \\
\pm 0.27\end{array}$ & $\begin{array}{r}4.83 \\
\pm 0.25\end{array}$ & $\begin{array}{r}0.81 \\
\pm 0.14\end{array}$ & $\begin{array}{r}1.34 \\
\pm 0.13\end{array}$ & $\begin{array}{r}189 \\
\pm \quad 35\end{array}$ & $\begin{array}{r}61 \\
\pm 13\end{array}$ & 3 & $\begin{array}{r}123 \\
\pm \quad 32\end{array}$ & $\begin{array}{r}225 \\
\pm \quad 28\end{array}$ & $\begin{array}{r}117 \\
\pm \quad 20\end{array}$ & $\begin{array}{r}98 \\
\pm \quad 23\end{array}$ \\
\hline $\mathbf{P}$ & & $<0.3$ & $<0.01$ & $<0.01$ & $<0.01$ & $<0.01$ & $<0.6$ & & $<0.01$ & $<0.01$ & $<0.02$ & $<0.01$ \\
\hline
\end{tabular}

B. Cord Plasma

\begin{tabular}{|c|c|c|c|c|c|c|c|c|c|c|c|c|}
\hline $\begin{array}{l}\text { Lee } \\
\text { Hof } \\
\text { Wal } \\
\text { Arb } \\
\text { Fuh } \\
\text { Wil } \\
\text { Cly } \\
\text { Coh } \\
\text { Vog } \\
\text { Lut } \\
\text { Lau } \\
\text { Wer } \\
\text { Lea } \\
\text { Nor } \\
\text { Lug } \\
\text { Sch } \\
\text { Har } \\
\text { Bro } \\
\text { Gil } \\
\text { Sev } \\
\text { San } \\
\text { Sta } \\
\text { Mot } \\
\text { Mah } \\
\text { Hef }\end{array}$ & $\begin{array}{l}\mathbf{M} \\
\mathbf{F} \\
\mathbf{F} \\
\mathbf{F} \\
\mathbf{F} \\
\mathbf{F} \\
\mathbf{F} \\
\mathbf{F} \\
\mathbf{F} \\
\mathbf{M} \\
\mathbf{M} \\
\mathbf{M} \\
\mathbf{F} \\
\mathbf{F} \\
\mathbf{F} \\
\mathbf{M} \\
\mathbf{M} \\
\mathbf{M}\end{array}$ & $\begin{array}{l}6.50 \\
5.70 \\
5.60 \\
6.38 \\
5.46 \\
5.81 \\
5.56 \\
6.37 \\
5.70 \\
6.44 \\
5.42 \\
5.02 \\
6.24 \\
4.64 \\
5.43 \\
5.79 \\
5.78 \\
6.07 \\
6.07 \\
5.21 \\
5.55 \\
5.71 \\
5.61 \\
6.10 \\
4.93\end{array}$ & $\begin{array}{l}4.36 \\
4.16 \\
3.98 \\
4.42 \\
3.93 \\
4.32 \\
4.07 \\
4.49 \\
3.95 \\
4.43 \\
3.94 \\
3.69 \\
4.26 \\
3.21 \\
4.23 \\
4.26 \\
4.13 \\
4.12 \\
4.22 \\
3.92 \\
3.98 \\
4.00 \\
3.26 \\
4.50 \\
3.72\end{array}$ & $\begin{array}{l}1.18 \\
0.83 \\
1.05 \\
1.09 \\
0.79 \\
0.81 \\
0.87 \\
1.16 \\
1.14 \\
1.21 \\
0.78 \\
0.55 \\
1.15 \\
0.64 \\
0.91 \\
0.81 \\
1.02 \\
1.13 \\
1.01 \\
0.81 \\
0.79 \\
1.01 \\
0.81 \\
0.89 \\
0.64\end{array}$ & $\begin{array}{l}1.34 \\
0.91 \\
0.81 \\
1.25 \\
0.97 \\
0.96 \\
0.83 \\
0.94 \\
0.79 \\
1.08 \\
0.97 \\
0.82 \\
1.07 \\
1.04 \\
0.85 \\
1.06 \\
0.92 \\
1.09 \\
0.98 \\
0.84 \\
1.07 \\
1.08 \\
0.74 \\
0.83 \\
1.11\end{array}$ & $\begin{array}{l}85 \\
67 \\
53 \\
85 \\
78 \\
81 \\
48 \\
73 \\
48 \\
81 \\
60 \\
48 \\
98 \\
71 \\
64 \\
82 \\
76 \\
67 \\
65 \\
50 \\
58 \\
52 \\
47 \\
89 \\
79\end{array}$ & $\begin{array}{l}27 \\
26 \\
14 \\
31 \\
28 \\
27 \\
23 \\
33 \\
28 \\
38 \\
24 \\
25 \\
26 \\
32 \\
35 \\
27 \\
48 \\
27 \\
29 \\
16 \\
29 \\
29 \\
14 \\
40 \\
30\end{array}$ & $\begin{array}{l}1 \\
0 \\
0 \\
4 \\
2 \\
0 \\
0 \\
0 \\
3 \\
3 \\
4 \\
2 \\
0 \\
0 \\
0 \\
2 \\
3 \\
3 \\
4 \\
0 \\
0 \\
0 \\
0 \\
0 \\
0\end{array}$ & $\begin{array}{l}38 \\
41 \\
33 \\
42 \\
40 \\
44 \\
26 \\
38 \\
15 \\
38 \\
34 \\
20 \\
65 \\
38 \\
29 \\
53 \\
28 \\
37 \\
31 \\
27 \\
29 \\
23 \\
29 \\
41 \\
51\end{array}$ & $\begin{array}{l}130 \\
105 \\
122 \\
138 \\
134 \\
145\end{array}$ & $\begin{array}{l}62 \\
63 \\
70 \\
84 \\
58 \\
65\end{array}$ & $\begin{array}{l}35 \\
30 \\
43 \\
27 \\
42 \\
37\end{array}$ \\
\hline $\begin{array}{l}\text { Mean } \\
\text { S.D. }\end{array}$ & & $\begin{array}{r}5.72 \\
\pm 0.48\end{array}$ & $\begin{array}{r}4.06 \\
\pm 0.33\end{array}$ & $\begin{array}{r}0.92 \\
\pm 0.19\end{array}$ & $\begin{array}{r}0.97 \\
\pm 0.15\end{array}$ & $\begin{array}{r}68 \\
\pm 15\end{array}$ & $\begin{array}{r}28 \\
\pm \quad 8\end{array}$ & $\begin{array}{r}1 \\
\pm 1\end{array}$ & $\begin{array}{r}36 \\
\pm 11\end{array}$ & $\begin{array}{r}124 \\
+\quad 22\end{array}$ & $\begin{array}{r}66 \\
\pm 10\end{array}$ & $\begin{array}{r}39 \\
\pm 12\end{array}$ \\
\hline
\end{tabular}


MM filter paper $(17 \times 35 \mathrm{~cm}$.) was suspended in a taut, horizontal position across two plastic rods spaced $18 \mathrm{~cm}$. apart in a movable plastic frame. The buffer vessels $(4 \times 4 \times 18 \mathrm{~cm}$.) were connected with $\mathrm{KCl}$-agar salt bridges to $100 \mathrm{ml}$. beakers containing platinum electrodes.

Prior to electrophoresis, the fractions were concentrated to approximately $4.0 \mathrm{gm}$. per $100 \mathrm{ml}$. protein solution in the same manner as described for the moving boundary method (1) but dialysis was not essential.

One-hundredth of a milliliter of ACD plasma and each of the concentrated fractions (IV + V + VI and I + III) were applied $1.5 \mathrm{~cm}$. apart in duplicate groups, thus making a total of eight samples per sheet of filter paper. A potential of approximately 7 to 9 volts per $\mathrm{cm}$. was supplied by a variable-voltage vacuum tube rectifier operating from a $110 \mathrm{AC}$ line.

Under these conditions complete resolution of the protein components was obtained after approximately five and one-half hours. The paper was dried in an oven and cut into two sections. One section (plasma, Fractions IV $+\mathrm{V}+\mathrm{VI}, \mathrm{II}$, and I + III) was stained with bromphenol blue for all protein components according to Goa (18); the duplicate section was stained with Sudan black B for lipoproteins according to Swahn (19).

\section{RESULTS}

Data of the fractionation and analyses of maternal plasma are presented in Table IA which also contains for sake of comparison mean values with standard deviation of 21 normal non-pregnant young women. Results on the cord plasma are recorded separately in Table IB but may be identified with those of the respective mothers by the symbols in the first column of the table.

\section{Maternal Plasma}

\section{Protein concentration and distribution}

There is little difference in the mean values for total protein in the normal and pregnant group, although the range among the pregnant women is somewhat greater. Variations in the concentration in Fraction IV + V + VI are considerable but the values are with one exception below the normal range. The concentration of proteins in Fraction II is significantly less than in the normal group, and in Fraction I + III it greatly exceeds that of non-pregnant women.

\section{Concentration and distribution of cholesterol and phospholipid}

In the plasma of pregnant women the concentrations of both cholesterol and phospholipid are greater than normal. The increment in cholesterol occurs entirely in the cholesterol in Fraction I+ III. The cholesterol in Fraction IV + V + VI is virtually identical in both groups. Also, with the phospholipids almost all the increase in the plasma concentration is found in Fraction I + III. In Table II are shown the derived data for the

TABLE II

Distribution of cholesterol and phospholipids and cholesterol-phospholipid ratios in maternal and cord plasma and fractions compared with similar values in the plasma of young non-pregnant women

\begin{tabular}{|c|c|c|c|c|c|c|c|}
\hline & \multirow[b]{2}{*}{$\begin{array}{l}\text { Plasma } \\
\text { Cholesterol-- } \\
\text { phospholipid } \\
\text { ratio }\end{array}$} & \multicolumn{3}{|c|}{ Fraction $I V+V+V I$} & \multicolumn{3}{|c|}{ Fraction I + III } \\
\hline & & $\begin{array}{c}\text { per cent } \\
\text { of total } \\
\text { cholesterol }\end{array}$ & $\begin{array}{c}\text { per cent } \\
\text { of total } \\
\text { phospholipids }\end{array}$ & $\begin{array}{l}\text { Cholesterol- } \\
\text { phospholipid } \\
\text { ratio }\end{array}$ & $\begin{array}{c}\text { per cent } \\
\text { of total } \\
\text { cholesterol }\end{array}$ & $\begin{array}{c}\text { per cent } \\
\text { of total } \\
\text { phospholipids }\end{array}$ & $\begin{array}{l}\text { Cholesterol- } \\
\text { phospholipid } \\
\text { ratio }\end{array}$ \\
\hline \multicolumn{8}{|c|}{$\begin{array}{l}\text { Pregnant women } \\
14 \text { Subjects } \\
\text { Aged 20-40 }\end{array}$} \\
\hline $\begin{array}{l}\text { Mean } \\
\text { S.D. } \\
\text { Range }\end{array}$ & $\begin{array}{c}0.84 \\
\pm 0.11 \\
0.73-1.06\end{array}$ & $\begin{array}{c}23.7 \\
\pm 7.3 \\
10.2-40.9\end{array}$ & $\begin{array}{c}40.8 \\
\pm 10.2 \\
24.2-59.9\end{array}$ & $\begin{array}{c}0.47 \\
\pm 0.08 \\
0.34-0.61\end{array}$ & $\begin{array}{c}75.5 \\
\pm 8.3 \\
57.7-88.6\end{array}$ & $\begin{array}{c}59.2 \\
\pm 9.9 \\
40.1-75.8\end{array}$ & $\begin{array}{c}1.07 \\
\pm 0.14 \\
0.89-1.34\end{array}$ \\
\hline \multicolumn{8}{|c|}{$\begin{array}{l}\text { Non-pregnant women } \\
24 \text { Subjects } \\
\text { Aged } 19-35\end{array}$} \\
\hline $\begin{array}{l}\text { Mean } \\
\text { S.D. } \\
\text { Range }\end{array}$ & $\begin{array}{c}0.84 \\
\pm 0.11 \\
0.59-1.08\end{array}$ & $\begin{array}{c}33.2 \\
\pm 8.9 \\
22.0-61.0\end{array}$ & $\begin{array}{c}54.5 \\
\pm 7.2 \\
38.2-78.3\end{array}$ & $\begin{array}{c}0.52 \\
\pm 0.06 \\
0.40-0.64\end{array}$ & $\begin{array}{c}65.2 \\
\pm 8.9 \\
37.0-77.9\end{array}$ & $\begin{array}{c}45.2 \\
\pm 8.0 \\
22.0-56.7\end{array}$ & $\begin{array}{c}1.25 \\
\pm 0.16 \\
0.91-1.56\end{array}$ \\
\hline \multicolumn{8}{|c|}{12 Cord plasmas } \\
\hline $\begin{array}{l}\text { Mean } \\
\text { S.D. } \\
\text { Range }\end{array}$ & $\begin{array}{c}0.57 \\
\pm 0.08 \\
0.44-0.66\end{array}$ & $\begin{array}{c}43.3 \\
\pm \\
28.7-61.0\end{array}$ & $\begin{array}{c}63.1 \\
\pm 9.5 \\
55.1-88.5\end{array}$ & $\begin{array}{c}0.44 \\
\pm 0.08 \\
0.28-0.57\end{array}$ & $\begin{array}{c}55.0 \\
\pm 9.6 \\
33.0-71.3\end{array}$ & $\begin{array}{c}36.9 \\
\pm 9.5 \\
11.5-44.9\end{array}$ & $\begin{array}{c}0.87 \\
\pm 0.14 \\
0.57-1.07\end{array}$ \\
\hline
\end{tabular}


maternal plasma. The percentage of total cholesterol in Fraction IV + V + VI is highly variable with many values within the normal range but with few considerably below it. The mean of 23.7 per cent is considerably below the normal mean of 33.2 per cent. Conversely, the mean percentage of cholesterol in Fraction I + III is increased above normal in the pregnant women.

The mean cholesterol-phospholipid ratio in whole plasma does not differ in the two groups. The ratio in Fraction I + III is somewhat variable but the mean is significantly lower than normal. This does not depress the plasma ratio because of the greater proportion of cholesterol and phospholipid in Fraction I + III.

\section{Cord Plasma}

\section{Protein concentration and distribution}

In the newborn infant the concentration of total protein is definitely less than that of the mother or of normal non-pregnant young women. In Fraction IV $+\mathrm{V}+\mathrm{VI}$, also, the concentrations of protein are slightly lower than the adult values although the percentage relative to total protein tends to be higher and approximates that of normal young adults. In Fraction II in which gamma globulins are concentrated, the values exceed considerably those of the mothers and of healthy non-pregnant young women. Both the concentration of protein and the percentage of the total protein in Fraction I + III average about double those of normal.

\section{Concentration and distribution of cholesterol and phospholipid}

In cord plasma, cholesterol and phospholipid concentrations are very much lower than those found in adults. The absolute amount of cholesterol in Fraction IV $+\mathrm{V}+\mathrm{VI}$ is about half that in normal young women; the cholesterol in Fraction I + III is about one-third that found in the normal females.

Cholesterol was usually recovered well in the fractions. The recovery of phospholipid was less complete. This may have been due in part to the omission of analysis in Fraction II. Where the total phospholipid is so low, loss of even a small amount is proportionately large. Because of the low concentrations of both cholesterol and phospholipids relatively small errors in analysis were extremely consequential in the calculation of cholesterol-phospholipid ratios.

In Table II, the means of the relative concentrations of cholesterol and phospholipid in the two fractions are shown together with the mean values for the cholesterol-phospholipid ratios. It will be seen that there is a high relative concentration of cholesterol in Fraction IV $+\mathrm{V}+\mathrm{VI}$ and a corresponding diminution in Fraction I + III. The cholesterol-phospholipid ratios are within the normal range in Fraction IV $+\mathrm{V}+\mathrm{VI}$ but considerably reduced in whole plasma and in Fraction I + III.

\section{Electrophoresis}

Moving boundary analysis of the plasma and fractions from normal pregnant women revealed the various electrophoretic components which are indicated in Table III as percentage area distribution. For comparison, the values of a normal young woman are included in the table. It may be seen that in maternal plasma the protein separation is of the same type as that obtained by Lever and his co-workers (20) and ourselves (1) for normal individuals. The albumin is concentrated chiefly in Fraction IV + V + VI with occasional trace amounts in Fractions II and I + III ; gamma globulin is found mainly in Fraction II with slightly greater than normal loss into Fraction I + III ; all of the fibrinogen is localized in Fraction I + III where also variable amounts of alpha and beta globulin appear.

The observations from paper electrophoresis with Sudan black B staining show that in both the normal non-pregnant and pregnant women all of the lipids in Fraction IV + V + VI are concentrated in the alpha $a_{1}$-albumin area, while those in Fraction I + III of the pregnant women appear in a slightly faster than normal beta ${ }_{1}$ globulin position. Lipids are demonstrable only occasionally in Fraction II where they are barely perceptible throughout the beta ${ }_{1}$ gamma globulin areas.

It is evident from the table that the percentage of albumin is lower, and that of alpha , alpha $_{2}$, and beta $_{1}$ globulins is higher in normal pregnant women. The decrease in albumin is reflected in 
TABLE III

Moving boundary electrophoretic analysis of plasma and fractions from pregnant and non-pregnant women. $A$ comparison of percentage area distribution of protein components

\begin{tabular}{|c|c|c|c|c|c|c|c|c|c|}
\hline Specimen & $\begin{array}{c}\text { Subject } \\
\text { Women 19-40 yrs. }\end{array}$ & $\begin{array}{c}\text { Albumin } \\
(\%)\end{array}$ & $\left(\begin{array}{l}\alpha_{1} \\
(\%)\end{array}\right.$ & $\begin{array}{l}\alpha \boldsymbol{q} \\
(\%)\end{array}$ & $\left(\begin{array}{c}\beta_{1} \\
\%\end{array}\right)$ & $\begin{array}{l}\beta_{2} \\
(\%)\end{array}$ & & $(\%)$ & $(\%)$ \\
\hline \multirow[t]{4}{*}{ Plasma } & \multirow{4}{*}{$\begin{array}{l}\text { Normal } \\
\text { non-pregnant } \\
\text { Normal } \\
\text { pregnant } \\
\text { Normal } \\
\text { pregnant } \\
\text { Normal } \\
\text { pregnant }\end{array}$} & 51.5 & 10.9 & 8.8 & 11.4 & - & 7.2 & - & 10.1 \\
\hline & & 42.9 & 11.5 & 10.0 & 17.8 & - & 8.3 & - & 9.6 \\
\hline & & 33.5 & 13.3 & 13.4 & 18.1 & - & 8.9 & - & 12.9 \\
\hline & & 40.5 & 14.9 & 11.8 & 16.5 & - & 8.1 & - & 8.2 \\
\hline \multirow[t]{4}{*}{$\begin{array}{l}\text { Fraction } \\
\text { IV+V+VI }\end{array}$} & \multirow{4}{*}{$\begin{array}{l}\text { Normal } \\
\text { non-pregnant } \\
\text { Normal } \\
\text { pregnant } \\
\text { Normal } \\
\text { pregnant } \\
\text { Normal } \\
\text { pregnant }\end{array}$} & 81.9 & 9.8 & 4.6 & 3.6 & - & & - & - \\
\hline & & 72.9 & 14.5 & 6.1 & 6.6 & - & & - & - \\
\hline & & 68.5 & 17.0 & 6.7 & 7.9 & - & & - & - \\
\hline & & 65.5 & 17.3 & 9.6 & 7.6 & - & & - & - \\
\hline \multirow[t]{4}{*}{$\begin{array}{l}\text { Fraction } \\
\text { II }\end{array}$} & \multirow{4}{*}{$\begin{array}{l}\text { Normal } \\
\text { non-pregnant } \\
\text { Normal } \\
\text { pregnant } \\
\text { Normal } \\
\text { pregnant } \\
\text { Normal } \\
\text { pregnant }\end{array}$} & - & - & - & - & 12.7 & & - & 87.4 \\
\hline & & 3.2 & - & - & 5.5 & 11.0 & & - & 80.4 \\
\hline & & 3.0 & - & - & - & 12.6 & & - & 84.3 \\
\hline & & - & - & - & - & - & & - & - \\
\hline \multirow[t]{4}{*}{$\begin{array}{r}\text { Fraction } \\
\text { I+III }\end{array}$} & \multirow{4}{*}{$\begin{array}{l}\text { Normal } \\
\text { non-pregnant } \\
\text { Normal } \\
\text { pregnant } \\
\text { Normal } \\
\text { pregnant } \\
\text { Normal } \\
\text { pregnant }\end{array}$} & - & 4.6 & 25.6 & 25.1 & 12.8 & & 23.2 & 8.7 \\
\hline & & - & 10.4 & 43.5 & 5.9 & 10.9 & & 20.9 & 9.0 \\
\hline & & 7.6 & 17.9 & 29.7 & 10.4 & 9.9 & & 15.1 & 9.4 \\
\hline & & - & 8.9 & 48.9 & 13.9 & - & 17.2 & - & 10.8 \\
\hline
\end{tabular}

Fraction IV + V + VI where there is also a moderate increase in alpha $a_{1}$ alpha $_{2}$, and beta globulins.

It should be mentioned that our values for percentage of total area as alpha ${ }_{1}$ globulin in plasma and in Fraction IV + V + VI of normal individuals recorded here and in a previous paper (1) are somewhat higher than those reported by other observers $(7,20)$. This may be attributed to the difficulties encountered in precise measurement of the alpha ${ }_{1}$ area which frequently resolves poorly in veronal-citrate buffer.

In Fraction II the percentage of gamma globulin is slightly lower than normal. In Fraction I + III variable amounts of the plasma increment of non-lipid-bearing alpha ${ }_{1}$ globulin appear. The increased percentage of alpha $_{2}$ globulin in this fraction is striking particularly in relation to the relative values for beta ${ }_{1}$ globulin which are not ostensibly augmented. The disproportion is per- haps more apparent than real and may be due in part to the faster than normal mobility of the beta $_{1}$ components. The migration of the beta peak as a long thin shoulder of a large alpha $a_{2}$ peak under which it is more than particularly buried, makes calculation of the two areas extremely difficult. All of the lipids in Fraction I + III as determined by paper electrophoresis are concentrated in this alpha $_{2}-$ beta $_{1}$ area. The fibrinogen recovered in Fraction I + III is variable in amount but unremarkable.

Cord plasma and its fractions have been analyzed only with the method of paper electrophoresis. With bromphenol blue stain the type of separation obtained with Cohn's method 10 for cord blood is the same as for adults. Albumin is concentrated almost entirely in Fraction IV $+\mathrm{V}$ + VI with variable amounts of alpha , alpha $_{2}$, and beta globulins. Noteworthy, however, is the unusually low concentration of alpha $a_{2}$ globulin in 
this fraction. The gamma globulin is almost entirely concentrated in Fraction II and only traces are found in Fraction I + III where fibrinogen, alpha $_{1}$, and alpha $_{2}$ globulins also appear but in amounts very low when compared with those of normal adults. The lipids are concentrated in Fraction IV + V + VI as alpha ${ }_{1}$ globulin and in Fraction I + III as beta ${ }_{1}$ globulins. As might be expected from the extremely low lipid values in cord blood, the stain with Sudan B is very faint.

\section{DISCUSSION}

\section{A. The concentration of protein in the fractions}

The data on protein concentrations of maternal plasma are consistent with the results of previous investigations using electrophoretic separation of the plasma proteins. The decrease in plasma albumin noted in those studies $(4,7)$ is masked in the Cohn fractionation since in Fraction IV + $\mathrm{V}+\mathrm{VI}$, which contains albumin, there is a considerable increase of alpha and beta globulins in the mothers' plasma. Fraction II, consisting largely of gamma globulin, is reduced in amount slightly and this is in agreement with the electrophoretic data. All previous studies have shown increases in maternal alpha and beta globulins, the influence of which is seen in the large increase in the amount of protein in Fraction I + III.

In cord plasma our results are in agreement with those of others that the total protein concentration is reduced. The reason for the reduction in protein in Fraction IV + V + VI cannot be given categorically in the absence of electrophoretic analysis of the fractions. In the study of Longsworth, Curtis, and Pembroke (4) a decrease in albumin was found in the cord plasma. In the study of Moore, DuPan, and Buxton (6) no such decrease occurred. In both studies alpha globulins were decreased. It is possible that the decrease in protein in Fraction IV + V + VI is due solely to a decrease in alpha globulins which are present in this fraction although the magnitude of the decrease suggests also some decrease in albumin concentration.

\section{B. The concentrations of lipids in the plasma and fractions}

The results of the study agree with others in the literature in their observation of an increased concentration both of cholesterol and of phospholipids in the maternal plasma. As in the study of Peters, Heinemann, and Man (10) the ratios of cholesterol and phospholipid in the plasma vary only within narrow limits. Examination of the fractions offers some information concerning the distribution of lipids between the two types of lipoproteins in the pregnant state. In Fraction $\mathrm{IV}+\mathrm{V}+\mathrm{VI}$ in which the lipids form a part of alpha lipoproteins, the concentrations of cholesterol and phospholipid are relatively diminished but absolutely unchanged. From this it may be inferred that at the time of delivery the pregnant woman's plasma contains alpha lipoproteins in approximately normal amounts. Our data offer no evidence from cholesterol-phospholipid ratios that the alpha lipoproteins differ in character from those in the plasma of nonpregnant women.

In Fraction I + III in which the lipids are combined chiefly if not entirely with beta ${ }_{1}$ globulins as beta lipoproteins the average concentration both of cholesterol and phospholipid is increased but with the phospholipid increment suffciently greater to cause a significant reduction of the cholesterol-phospholipid ratio of the fractions and to indicate the possibility of abnormal lipid combinations with globulins.

Cord plasma. The low concentration of cholesterol and phospholipids in fetal plasma is well illustrated by our data. Fraction IV $+\mathrm{V}+\mathrm{VI}$ contains a relatively high proportion of the total lipids. Cholesterol-phospholipid ratios deviate little from normal and are consistent with those of normally constituted alpha lipoproteins. Fraction I + III with the lowest lipid concentration thus far found in our experience with human plasma reveals cholesterol-phospholipid ratios so low as to suggest either unusual lipoproteins or variant mixtures of the lipoproteins which compose the fraction in normal adults.

The depressed ratios of cholesterol to phospholipid in Fraction I + III and the relative concentration of lipids in Fraction IV + V + VI combine to explain the low cholesterol-phospholipid ratios of the unfractionated plasma.

Relation of hormones to chemical deviations in the plasma of pregnancy and the newborn. Since the pregnant woman at term is producing large amounts of estrogen, it might be suspected that 
estrogen stimulation is responsible for some of the chemical disturbances that have been recorded in maternal and fetal plasma. Work in our laboratory reported elsewhere has shown that the administration of large amounts of estrogen to adults produces several predictable changes in the concentration and distribution of lipids (3). It usually causes a fall in the concentration of the total cholesterol in the plasma. It changes the distribution of cholesterol in such a manner that a large part of the total is concentrated in Fraction IV $+V+V I$ presumably in the form of alpha lipoproteins. It causes a fall in phospholipid concentration greater than that observed for cholesterol, a change which is especially notable in Fraction I + III where the cholesterol-phospholipid ratios are definitely lower than under normal conditions.

In maternal plasma there is little to indicate that the protein-lipid pattern has been changed in a direction which would be expected from an unmodified estrogen effect. In the plasma of the infant all of the deviations expected from administration of estrogen are evident. The total cholesterol concentration is low, the percentage of total cholesterol in Fraction IV $+\mathrm{V}+\mathrm{VI}$ is high, and the cholesterol-phospholipid ratios in the plasma and in Fraction I + III fall below normal. It is not impossible that some or all of these changes are related to the physical alterations in genitalia and breasts so frequently observed in newborn infants and usually attributed to temporary stimulation by estrogens. Significance may also be attached to the experience that these changes so evident at the moment of birth are lost after a few weeks of extra-uterine life.

The question raised by these comments can be answered only by further investigation. It is probable that the estrogen influence is only one of many which modify or change protein-lipid relationships during the complicated state of pregnancy and fetal development.

\section{SUM MARY}

Plasma taken from pregnant women at the time of their delivery and simultaneously from the umbilical cords of their newborn infants has been fractionated by Cohn's method 10 . The whole plasma and its fractions have been analyzed for protein, cholesterol, and phospholipids.

Moving boundary and paper electrophoretic methods have been used to confirm the separation of protein components in selected cases. These determinations have shown that the protein separation is of the same type as that seen in normal adults, and that alpha lipoproteins are concentrated in Fraction IV + V + VI while beta lipoproteins accumulate in Fraction I + III. The beta lipoproteins in Fraction I + III of maternal plasma migrate electrophoretically somewhat faster than do those of normal non-pregnant women.

The study lends support to observations of previous observers that in the maternal plasma the concentration of albumin is reduced and that the concentrations of alpha and beta globulins as well as of cholesterol and phospholipids are increased; also that in cord plasma the concentrations of total protein, alpha and beta globulins, total cholesterol, and total phospholipids are less than in adult plasma.

In maternal plasma the distribution of cholesterol and phospholipids between the lipoproteins of plasma is frequently but not invariably altered so that the amount combined with alpha lipoproteins is relatively diminished and the amount combined with the proteins of Fraction I + III is relatively increased. The lipoproteins in Fraction I + III have a significantly lower than normal cholesterol-phospholipid ratio. In cord plasma the distribution of lipids between the lipoproteins deviates from that of adult plasma in such a way that a relatively greater amount is found in the fractions containing alpha lipoproteins and correspondingly less in those containing beta lipoproteins. The cholesterol-phospholipid ratios of the fraction containing beta lipoproteins are considerably reduced, and the ratios of the unfractionated plasma are far lower than those found in adults.

Although both the maternal and fetal organisms are admittedly exposed to gross stimulation of estrogen, the cholesterol-phospholipid relationships in the mother's plasma fail to show the effects observed after administration of estrogen. The infant exposed to the same stimulus displays changes which might possibly be attributed to an estrogen effect. 


\section{REFERENCES}

1. Russ, E. M., Eder, H. A., and Barr, D. P., Proteinlipid relationships in human plasma. I. In normal individuals. Am. J. Med., 1951, 11, 468.

2. Barr, D. P., Russ, E. M., and Eder, H. A., Proteinlipid relationships in human plasma. II. In atherosclerosis and related conditions. Am. J. Med., 1951, 11, 480.

3. Barr, D. P., Russ, E. M., and Eder, H. A., Influence of estrogens on lipoproteins in atherosclerosis. Tr. A. Am. Physicians, 1952, 65, 102.

4. Longsworth, L. G., Curtis, R. M., and Pembroke, R. H., Jr., The electrophoretic analysis of maternal and fetal plasmas and sera. J. Clin. Invest., 1945, $24,46$.

5. Lagercrantz, C., Electrophoretic analysis of serum in pregnancy and in pregnancy toxemia. Upsala läkaref. förh., 1945, 51, 117.

6. Moore, D. H., DuPan, R. M., and Buxton, C. L., An electrophoretic study of maternal, fetal, and infant sera. Am. J. Obst. \& Gynec., 1949, 57, 312.

7. Macy, I. G., and Mack, H. C., Physiological Changes in Plasma Proteins Characteristic of Human Reproduction. Cross Sectional and Longitudinal Electrophoretic Data for Women During and Following Uncomplicated and Complicated Pregnancies. Detroit, Children's Fund of Michigan, 1951, $170 \mathrm{p}$.

8. Von Latzka, A., Die Strukurveränderung von Blutplasmaeiweiss während der normalen Schwangerschaft. Arch. f. Gynäk., 1931, 147, 120.

9. Boyd, E. M., and Wilson, K. M., The exchange of lipids in the umbilical circulation at birth. J. Clin. Invest., 1935, 14, 7.

10. Peters, J. P., Heinemann, M., and Man, E. B., The lipids of serum in pregnancy. J. Clin. Invest., 1951, 30, 388.
11. Boyd, E. M., Lipid composition of blood of newborn infants. Am. J. Dis. Child., 1936, 52, 1319.

12. Goldwater, W. H., and Stetten, D., Jr., Studies in fetal metabolism. J. Biol. Chem., 1947, 169, 723.

13. Smith, C. A., The Physiology of the Newborn Infant. 2nd ed., Springfield, Charles C Thomas, 1951, 348 p.

14. Cohn, E. J., Gurd, F. R. N., Surgenor, D. M., Barnes, B. A., Brown, R. K., Derouaux, G., Gillespie, J. M., Kahnt, F. W., Lever, W. F., Liu, C. H., Mittelman, D., Mouton, R. F., Schmid, K., and Uroma, E., A system for the separation of the components of human blood: Quantitative procedures for the separation of the protein components of human plasma. J. Am. Chem. Soc., 1950, 72, 465.

15. McDonald, H. J., Ionography: A new frontier in electrophoresis. J. Chem. Educat., 1952, 29, 428.

16. Flynn, F. V., and de Mayo, P., Micro-electrophoresis of protein on filter-paper. Lancet, 1951, 2, 235.

17. Cremer, H., and Tiselius, A., Elektrophorese von Eiweiss in Filtrier-papier. Biochem. Ztschr., 1950, 320, 273.

18. Goa, J., A simplified method for the separation and quantitative determination of serum proteins by paper electrophoresis. Scandinav. J. Clin. \& Lab. Invest., 1951, 3, 236.

19. Swahn, B., A method for localization and determination of serum lipids after electrophoretical separation on filter paper. Scandinav. J. Clin. \& Lab. Invest., 1952, 4, 98.

20. Lever, W. F., Gurd, F. R. N., Uroma, E., Brown, R. K., Barnes, B. A., Schmid, K., and Schultz, E. L., Chemical, clinical, and immunological studies on the products of human plasma fractionation. XL. Quantitative separation and determination of the protein components in small amounts of normal human plasma. J. Clin. Invest., 1951, 30, 99. 